\title{
A Volgográdi Állami Egyetem Történeti, Regionális Tudományi és Nemzetközi Kapcsolati Értesítőjének elmúlt évtizede (2010-2019) a számok tükrében
}

\author{
Quantitative Analyses of the Last Decade of Vestnik VolSU Series 4. History, Regional Studies \\ and International Relations (2010-2019)
}

The present review article is an attempt to analyse a well-determined interval of an internationally accredited Russian regional periodical: Vestnik of Volgograd State University. Series 4. History, Regional Studies and International Relations. The history of the periodical, which is devoted to a broad range of social sciences, is remarkably can be divided into two stages: after 2013 it became a nationwide journal. The periodical's restructuring was initiated by former chief editor I. I. Kurilla, but it was finished by current chief editor I. O. Tyumentsev, who developed the journal to an international level inter alia with the help of thematic issues, such as the Byzantine project or the conference materials dedicated to the $400^{\text {th }}$ anniversary of the Troubled Times.

Despite the above-mentioned successes, the statistical analysis of the data denotes some structural characteristics of competing scientific life in Russia. E.g. the distribution of the authors' gender indicates a more and more patriarchal pattern, while the scientific degree of them shows a growing elitization. Also the analysis of the authors' affiliation (city) points to a quite centralised structure of science. The progression of the headings shows a massive shift toward historical sciences (Russian history, World history, archaeology) to the detriment of other social sciences (political science, regional studies, international relations), which indicates the most competitive fields of the periodical.

The application of keywords represents a huge diversity, although they help us to determine main issues, or so called "hot topics". In the field of Russian history this "hot topic" is the Great Patriotic War, since Volgograd (Stalingrad) was a main battlefield during these challenging years.

Keywords: Vestnik VolSU, review, statistics, science metrics, big data analysis, sociology of science, hot topics of Russian social sciences, I. O. Tyumentsev

Viktor Szabó - PhD student, Doctoral Program of Russistics, Doctoral School of History, Faculty of Humanities, Eötvös Loránd University (Hungary, Budapest, 1088 Múzeum krt. 6-8.). e-mail: szaboviktor@student.elte.hu 
A Volgográdi Állami Egyetem egyike a Volga-vidék regionális oktatási, kutatási és tudományos központjainak. Az egyetem összesen 13 tudományos folyóiratot ad ki. ${ }^{1}$ Ebből 7 folyóirat 2015. december 1-jétől azon recenzált tudományos kiadványok listájába tartozik, amelyeket az Oroszországi Föderáció Oktatásügyi Minisztériuma alá tartozó Legfelsőbb Minősítő Bizottság arra javasolt, hogy teret adjon a kandidátusi és doktori fokozataikat megszerző kutatók számára disszertációjuk publikálásához. Ezek közül pedig mindössze egy folyóiratnak sikerült bekerülnie az Elsevier által üzemeltetett Scopus online adatbázisába, amelynek teljes címe: Вестник Волгоградского государственного университета. Серия 4. История. Регионоведение. Международнье отномения.

Már a címadásból is látszik, hogy az 1996-ban alapított folyóirat nem egy tudományágra, hanem a társadalomtudományok területének széles spektrumára specializálódott. A történelmen belül különösen hangsúlyt kap a régészet, Oroszország története és az egyetemes történelem. Vagyis az ősidőktől a jelenkorig nyomon követhetjük a történeti folyamatokat, amelyek meghatározzák a jelenleg is zajló gazdasági, társadalmi és politikai fejlődés kereteit. Ez utóbbiakkal a politológia, a nemzetközi kapcsolatok elemzése és a regionális földrajz (regionális tudományok) foglalkozik. Ebből az is látható, hogy mind a globális, mind az országos szintű, mind a lokális jelenségekkel kapcsolatos kutatásokat le kívánják fedni, bár érthető módon - az egyetemes témáknál is elsősorban a világ és Oroszország viszonya kerül fókuszba.

A folyóirat online archívumában a 2010-től megjelent cikkek találhatóak meg. ${ }^{2}$ Ez a kezdődátum lehetőséget biztosít arra, hogy jól körülhatárolható, „kerek” intervallumot, az elmúlt 10 évet (2010-2019) megvizsgálva vonjunk mérleget a Vesztnyik-röl. Az évtized összes cikkének alapadatait táblázatba rendezve és az adatokat elemezve tehetünk néhány tudománymetriai megállapítást, egyúttal pedig azt is megkísérelhetjük, hogy az egyes tudományágakon belüli témákból egyfajta tendenciát határozzunk meg, milyen „,forró témák” izgatták az elmúlt 10 évben a kutatókat.

\footnotetext{
1 «Журналы ВолГУ» волгоградский государственный университет, https://volsu.ru/struct/generalservices/publish/vestniki// (Дата обращения: 8. сентября 2020 г.).

2 «Архив» Вестник Волгоградского государственного университета. История. Регионоведение. Международные отношения, https://hfrir.jvolsu.com/index.php/ru/archive-ru (Дата обращения: 8 сентября 2020 г.).
} 


\section{Módszertan}

Ahhoz, hogy részletes kvantitatív elemzéseket lehessen elvégezni, első lépésként szükséges volt egy olyan adatbázist létrehozni, amelyben a folyóiratra, szerzőire és cikkeire vonatkozó összes fontos adat együtt, feldolgozható és ezt követően vizualizálható formában szerepel.

Ennek megfelelően készült egy tábla, amelyen a folyóirat alapvető adatai szerepelnek (évfolyam, kötetszám, oldalszám, cikkek száma, példányszám, tematikus számról van-e szó). Itt a 2010-2019 közötti lezárt időszakot vizsgáltuk, a 2020-ban azóta megjelent három számmal nem foglalkoztunk.

A következő táblán a szerzők alapadatai kerültek kigyüjtésre: a szerzők neve, neme, affiliációja (város, intézmény, szervezeti egység, beosztás) és tudományos fokozata. Ezzel kapcsolatban fontos megjegyezni, hogy egyes szerzők természetesen többször is publikálhattak, és egy cikk is lehetett több szerzős, ráadásul egy adott szerző intézményi hovatartozása és tudományos fokozata is változhatott idővel. Ezért az a megoldás lett alkalmazva, hogy minden egyes cikk minden egyes szerzője külön entitást képezzen. Ez alól egy elemzés kivétel, amikor azt vizsgáltuk, hogy ki a legtermékenyebb, legtöbbször publikáló szerző a folyóiratban.

A harmadik táblán a cikkek részletes adatait vettük fel: rovat (és alrovat) címe, szerző(k), cím, kulcsszavak, kezdő és záró oldalszám, a cikk elektronikus elérési útvonala. Ezeknél némileg nehezítette a helyzetet, hogy több tematikus számnál - mivel nem mindegyiknél, ezért nem lehetett szisztematikusként értelmezni - a szokásostól eltérő egyedi rovatmegnevezéseket alkalmaztak. Mivel minden esetben egyértelmünek nevezhető, hogy melyik állandó rovathoz, avagy tudományághoz tartozó témáról van szó (pl. a bizantinológia az egyetemes történelemhez került, a sztálingrádi csata Oroszország történetéhez stb.), ezért a tematikus cikkek kaptak egy állandó rovathoz való besorolást, és az egyedi rovatmegnevezés alrovatként került be. Azonban egyes vizsgálatok esetében torzíthatnak ezek az imaginárius rovatmegnevezések, így külön jelezzük, ha a tematikus számokat nem vettük figyelembe.

\section{Munkahipotézis}

A fenti adatok felvételével és elemzésével a célunk kvantitatív és kvalitatív vizsgálatok elvégzése a folyóirat történetével és tartalmával kapcsolatban: 
Az általános adatok alapján számokban bemutatható a kiadvány élete és fejlődése a vizsgált időintervallumban.

A szerzők adatai alapján szeretnénk megvizsgálni, mennyire kiegyensúlyozott a folyóirat genderszempontból, illetve mennyire segíti a tudományos előremenetelt. A szerzők affiliációjából pedig azt szeretnénk kideríteni, hogy milyen kiterjedt a regionális, országos és globális kapcsolatrendszere a kiadványnak.

A cikkekre vonatkozó adatok közül egyrészt fontosak a rovatok adatai. Ez alapján szeretnénk meghatározni, mely tudományág a leghangsúlyosabb a folyóirat profiljában, és ez hogyan változott az időben. Másrészt a kulcsszavak alapján kísérletet teszünk annak megvizsgálására, hogy összességében és az egyes tudományágakon belül melyek a legfontosabb témák.

A kulcsszavak vizsgálata egyúttal kapcsot jelent a kvalitatív vizsgálat felé. Ha sikerül meghatározni az ún. „forró témákat”, rátérünk néhány ezekkel kapcsolatos kiemelkedő cikk ismertetésére. Emellett megnézzük, hogy kifejezetten a történeti ruszisztika szükebb tárgykörében, azaz az Oroszország történetével foglalkozó rovatokban milyen aktuális témák lelhetök fel.

A legnagyobb kattintás-számmal rendelkező, tehát praktikusan a legnépszerübb cikkek szemlézése után ${ }^{3}$ pedig néhány magyar vonatkozást is említésre kerül.

\section{Az adatok elemzése}

\section{Alapadatok}

Ahogy már említésre került, a 2010-2019 közötti időszakot vontuk be a kvantitatív elemzésekbe. Ezen periódus alatt a folyóiratnak 44 száma jelent meg nyomtatott (minden esetben 500 példányban) és elektronikus formában. A köteteket az évfolyam és az azon belüli szám megadásával azonosították (a vizsgált időszakra a 15. évfolyam 1. szám - 24. évfolyam 6. szám esett), de eleinte ezzel párhuzamosan az 1996-os első kötettől kezdődő folyamatos számozást is alkalmaztak, amit később elhagytak. Ebből kiderül, hogy a 15. évfolyam 1. száma

\footnotetext{
${ }^{3}$ Az ezzel kapcsolatos adatokért köszönet illeti a Vesztnyik VolGU szerkesztőségét.
} 
a sorozat 17. darabjának felelt meg, vagyis valamikor a 2010 előtti néhány évben válthattak féléves periodicitásra, előtte éves kiadvány volt. 2014-től jelentős változásra került sor, amely a folyóirat életében egy markánsan új periódust jelentett. Ahogy a 2014-es első szám főszerkesztői előszavában olvasható, a folyóirat ekkor vált országos jelentőségüvé, s ennek keretében negyedéves megjelenést, valamint két tematikus szám megjelentetését tervezték évente, megőrizve a regionális jelleget, teret biztosítva a Volgográd, a Volga-vidék és DélOroszország kutatóinak. ${ }^{4}$ A tematikus számok ugyan várattak magukra 2015-ig, de hat szám azóta is stabilan megjelenik évente.

Ezt az átalakítást a terjedelem és a publikációk száma egy darabig megsínylette, de 2015-től ismét emelkedésnek indult, s az alábbi két ábrán jól látható, hogy mára már évi hat számot is meg tudnak tölteni majdnem ugyanannyi tartalommal, mint korábban kettőt.

2010-2019 között összesen 850 cikk jelent meg 8398 oldalon. A cikkek elrendezése kéthasábos, a nemzetközi sztenderdeknek megfelelően orosz és angol nyelvü rezümével, kulcsszavakkal, és kétnyelvü szakirodalmi listával ellátva. Gyors fejszámolással az is kikövetkeztethető, hogy átlagosan 10 oldalas egy cikk, vagyis többnyire 20-30 ezer karakter

\section{Cikkek számának változása (2010-2019)}

40
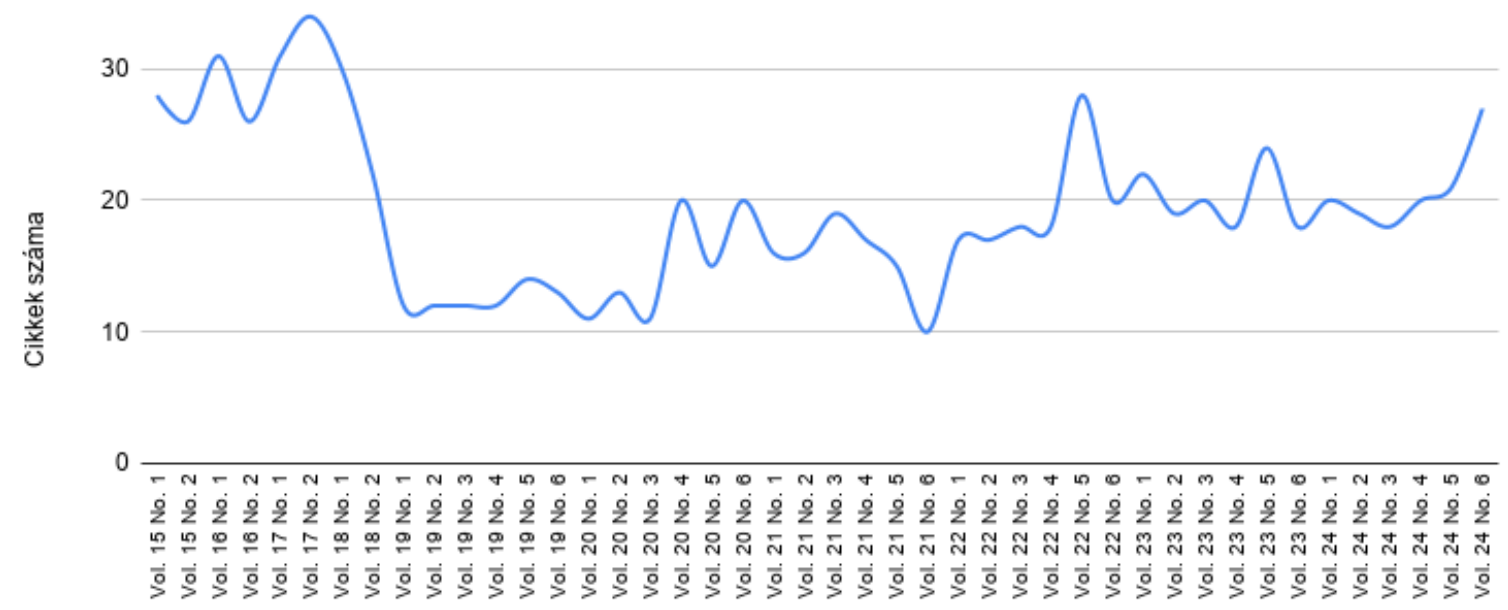

Kōtetszám

4 И.И. КуРИлЛА, «Обращение главного редактора» Вестник Волгоградского государственного университета. Серия 4, История. Регионоведение. Международные отношения, Vol. 19. no. 1 (2014), https:/hfrir.jvolsu.com/index.php/ru/component/attachments/download/639 (Дата обращения: 8 сентября 2020 г.) 
terjedelmü írásokat fogadnak be, de a következő ábrán látható, hogy a cikkek hossza lassan növekvő tendenciát mutat:

\section{Cikkek átlagos hosszának változása (2010-2019)}

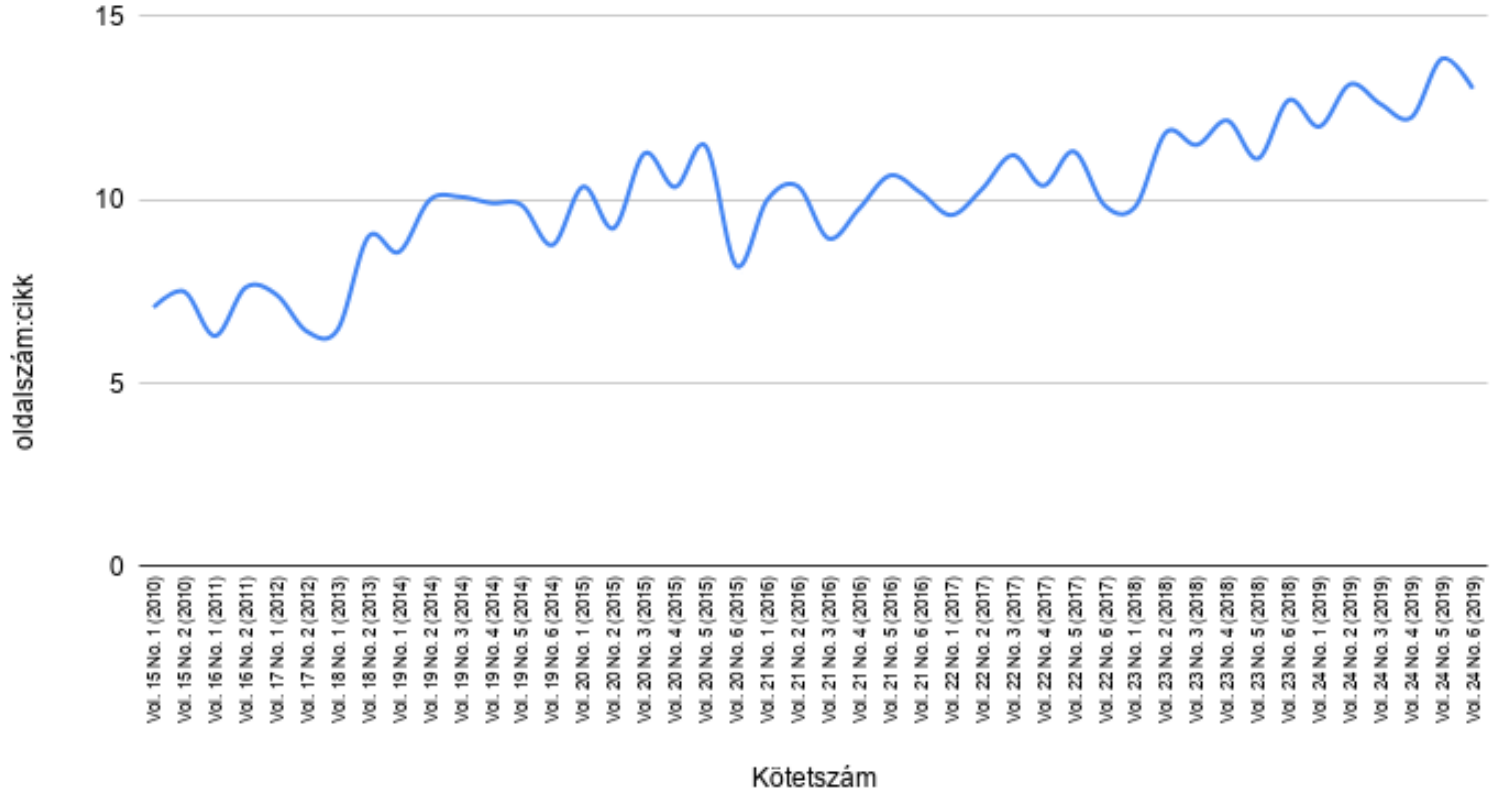

Az átalakítás utáni „tartalomínségen” segített egyrészt a korábban már említett, 2015 végén megszerzett minősítés, másrészt az, hogy a lefedett tudományterületek egy-egy kiemelt kutatási projektjéhez és/vagy jeles évfordulókhoz köthetően szervezett tudományos konferenciák anyagait is itt kezdték publikálni tematikus számok formájában.

A 2015-ös 20. évfolyam 3. kötetétől kezdve összesen 13 tematikus szám jelent meg. Ezek közül 5 a Volgográdi Állami Egyetem több éves nemzetközi jelentőségü bizantinológiai projektjéhez köthetö (20. évf. 3. sz.; 21. évf. 5. sz.; 22. évf. 5.sz.; 23. évf. 5.sz.; 24. évf. 6.sz.). Egy másik jelentős, az egyetem által elnyert projekt pedig Oroszország hadtörténetét volt hivatott feldolgozni. Ehhez kapcsolódóan jelentek meg a Nagy Honvédő Háborúban aratott győzelem 70. évfordulójának (20. évf. 4. sz.), a krími háborúnak (21. évf. 6. sz.), és a sztálingrádi csata 75. évfordulójának (23. évf. 1. sz.) szentelt kötetek. Ezeken kívül megtalálhatjuk még két régészeti konferencia anyagait (20. évf. 5. sz.; 23. évf. 3. sz.), az 1917-es forradalom 100. (22. évf. 6. sz.) és a „zavaros időszak” 400. évfordulójára (24. évf. 2. sz.) kiadott, valamint egy kozákság társadalomtörténetével foglalkozó tematikus lapszámot (24. évf. 4. sz.).

A vizsgált időszakban a folyóiratnak két főszerkesztője volt. 2010-2015 között Ivan Ivanovics Kurilla (1967-) történész, Amerika-kutató töltötte be ezt a tisztséget, 2015 végétől pedig Igor 
Olegovics Tyumencev (1958-) történész, Moszkóvia és a kozákság szakértője vette át tőle a szerkesztést. A 2014-ben beharangozott tervekből és a 2015-ös váltásból következik, hogy bár az átalakítást Kurilla kezdeményezte, a folyóirat országos és nemzetközi elismertségének kivívása, valamint a tematikus számok beindítása már Tyumencevnek köszönhető. A két főszerkesztő személye, kutatási területe is nagymértékben befolyásolta a folyóirat profilját. Ahogy a későbbiekben látni fogjuk, Kurilla idején egyfajta egyensúlyra törekedtek a tudományágak között, Tyumencev idején viszont erőteljes elmozdulás tapasztalható a régészet, az egyetemes és a hazai történelem irányába, amelyek ma már egységes tanszéket is alkotnak a Volgográdi Állami Egyetemen.

\section{A szerzők (gender, tudományos fokozat, intézményközi kapcsolatok)}

A következőkben a szerzők néhány adatát vizsgáljuk meg. A 850 publikációhoz összesen 1071 szerzőség köthető. Ebből is látszik, hogy bár dominálnak a klasszikus egyszerzős cikkek, azért előfordul, hogy egy tanulmányt több szerző jegyez. Különösen a természettudományos módszereket is igénybe vevő publikációknál figyelhető meg ez, ahol egy esetben hatszerzős cikk is elöfordul. ${ }^{5}$

Az 1071 szerzőség 673 különböző személyhez köthető, azaz vannak többször, illetve rendszeresen publikáló kutatók. Összességében a szerzők 71\%-a (478 fö) csak egyszer publikált a folyóiratba, a maradék 29\% teszi tehát ki az állandó szerzőgárdát. Közülük a legaktívabb 12 cikkel (15. évf. 1. szám; 16. évf. 1. sz.; 18. évf. 1. sz.; 19. évf. 4. sz.; 20. évf. 1. sz., 2. sz. [2 cikk], 6. sz.; 21. évf. 6. sz.; 22. évf. 6. sz.; 23. évf. 2. sz.; 24. évf. 4. sz.) Szergej Anatoljevics Pankratov, ${ }^{6}$ a politikatudományok doktora, akinek szakterülete a mai orosz politikai rendszer. A Volgográdi Állami Egyetem Nemzetközi Kapcsolatok, Regionális Tudományok és Politológia Tanszékének professzoraként találkozunk először vele, majd 2013-tól az immár különálló Politológia Tanszék vezetője, amely 2016-tól - némileg felcserélve a sorrendet ismét Nemzetközi Kapcsolatok, Politológia és Regionális Tudományok Tanszék.

\footnotetext{
5 Л.А. КРАЕВА, М. РАДИВОЕВИЧ, И.Г. РАВИЧ, Л.П. ЧЕРНИКОВА, И.А. ШУТЕЛЕВА, Н.Б. ЩЕРБАКОВ, «КИТаЙСКОе зеркало из позднесарматского комплекса «Черный Яр»». Вестник Волгоградского государственного университета. Серия 4, История. Регионоведение. Международные отношения, Vol. 23. no. 3. (2018): 176-188. DOI: 10.15688/jvolsu4.2018.3.16, https://hfrir.jvolsu.com/index.php/ru/component/attachments/download/1716 (Дата обращения: 8 сентября 2020 г.)

6 «Панкратов Сергей Анатольевич», Волгоградский государственный университет, https://volsu.ru/persons/id/?id=000000567 (Дата обращения: 8 сентября 2020 г.)
} 
Nem sokkal marad el Pankratovtól 10 cikkel (15. évf. 1. és 2. sz.; 16. évf. 1. sz.; 17. évf. 1. és 2. sz.; 20. évf. 5. sz.; 21. évf. 2. sz.; 22. évf. 1. sz.; 23. évf. 3. sz.; 24. évf. 5 sz.) Marija Afanaszjevna Balabanova, ${ }^{7}$ a történelemtudományok kandidátusa, majd 2015-től doktora. Az ő szakterülete a szarmaták régészete, azon belül a paleoantropológia, a paleodemográfia, a temetkezési szokások és a koponyatorzítások vizsgálata. Ö ugyancsak a Volgográdi Állami Egyetem kötelékébe tartozik, és docensként, majd doktori disszertációja megvédése után professzorként a Régészet és Egyetemes Történelem Tanszéken dolgozott, amelynek 2015-től Régészet, Egyetemes Történelem és Turizmus Tanszék, 2018-tól Orosz és Egyetemes Történelem, Régészet Tanszék a neve.

A két „rekorder” mögött még hárman vannak 8, hatan 7, öten 6 publikációval, akik állandó szerzőknek tekinthetők, innentől pedig jönnek a kevésbé rendszeres visszatérők: 5 ill. 4 cikkel tizenhatan, 3 cikkel harmincheten, 2 cikkel száztízen rendelkeznek.

Bár üdvözlendőnek tekinthető, hogy az első két helyen egy férfi és egy nő áll, azonban ha a teljes szerzőségi palettát végignézzük gender-szempontból, már nem ilyen kiegyensúlyozott a kép. 


\section{férfi és női szerzők számának változása (2010-2019)}

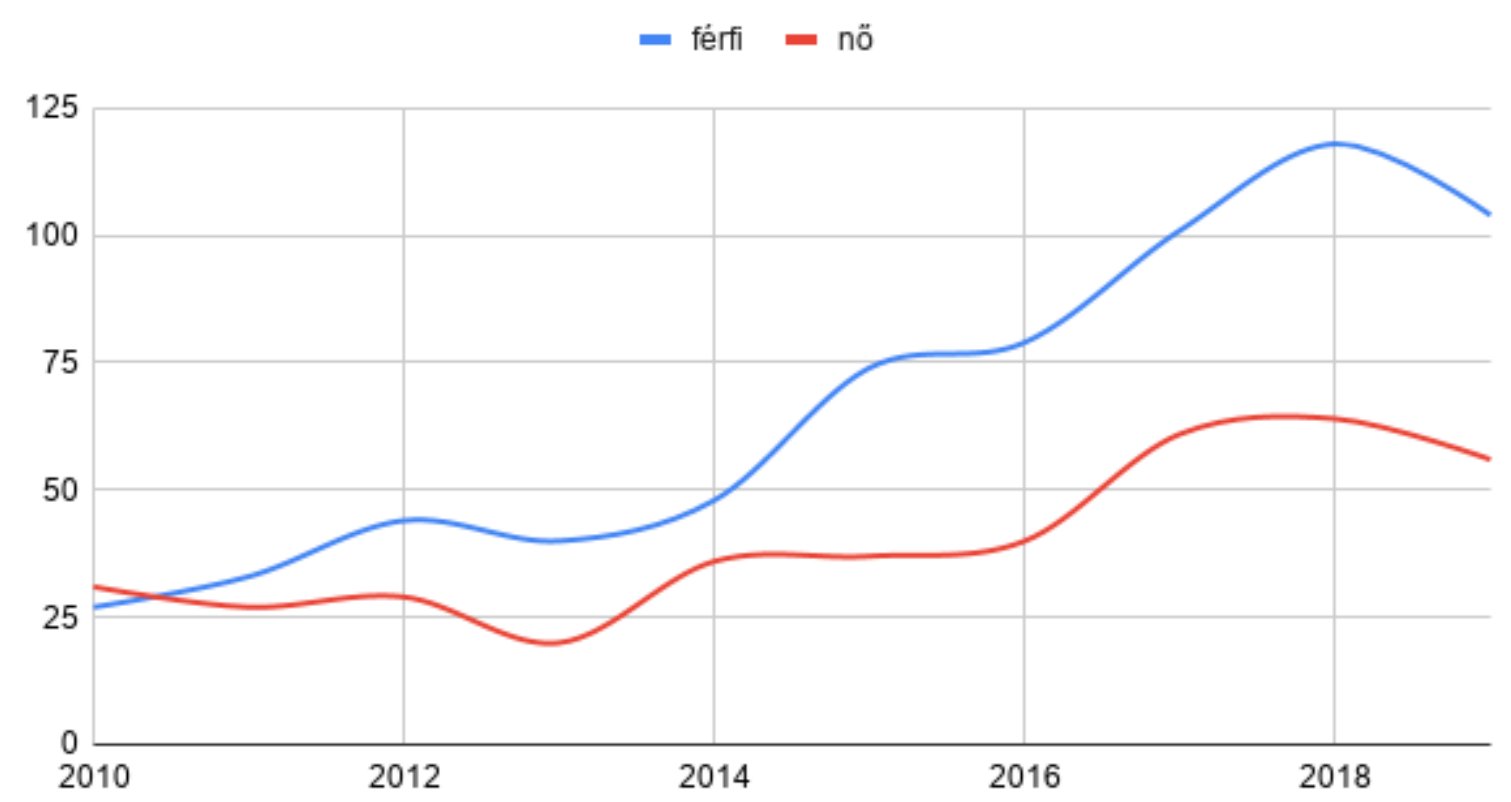

Azt kell látnunk, hogy míg 2010-ben még kiegyenlített volt a férfiak és nők aránya, sőt a nők még többen is voltak valamivel (47:53 a nők javára), addig ez a „gender-olló” egyre inkább kinyílt az idő előrehaladtával a férfiak javára. 2019-ben a férfi:nő arány már 65:35 volt, s közelíti az egész időszakra vetített 62,5:37,5-ös arányt.

A Kommerszant-ban nemrég megjelent tudósítás szerint globális méretű kutatást végeztek a gender-egyenlőtlenség kimutatására a tudomány területén 1955-2010 között. ${ }^{8}$ Eszerint Oroszország nem állt rosszul, hiszen a II. világháború utáni súlyos férfihiány, a nemek közti egyenlőséget hirdető szovjet propaganda kiegyenlítette ezeket a különbségeket, amelyek hatása 2010-ben még érzékelhető volt. Azonban a rendszerváltás után egyre inkább felértékelődtek a hagyományos nemi szerepek, a női és férfi kutatók fizetésének különbségei, a tudományos előremenetel lehetőségei egyre áthatolhatatlanabb „üvegplafont” teremtenek a nők számára, ami miatt jóval többen hagyják el a kutatói, oktatói pályát, vagy bele sem kezdenek. Mindehhez részben hozzájárulhatott a folyóirat presztízsének növekedése is, ennek következtében ugyanis egyre több magasabban jegyzett kutató publikálhatott, akik között arányaiban kevesebb a nő a tudományos előmenetelt hátráltató tényezők miatt.

\footnotetext{
8 «Гендерное неравенство в науке сохраняется и даже усиливается, как показывают последние данные», Коммерсантъ, 10 марта 2020 года, https://www.kommersant.ru/doc/4283709 (Дата обращения: 8 сентября 2020 г.)
} 
Összességében tehát egyre patriarchálisabb viszonyokat figyelhetünk meg az orosz tudományos életben. Emellett a folyóirat presztízsének növekedése sem feltétlenül a kívánt eredményeket hozta el. A következő ábrán a tudományos fokozattal nem rendelkező, kandidátusi, ill. doktori fokozatot szerzett, valamint egyéb (az orosz akadémiai struktúrába nem beleilleszthető) tudományos fokozattal bíró szerzők számának időbeli változását követhetjük nyomon:
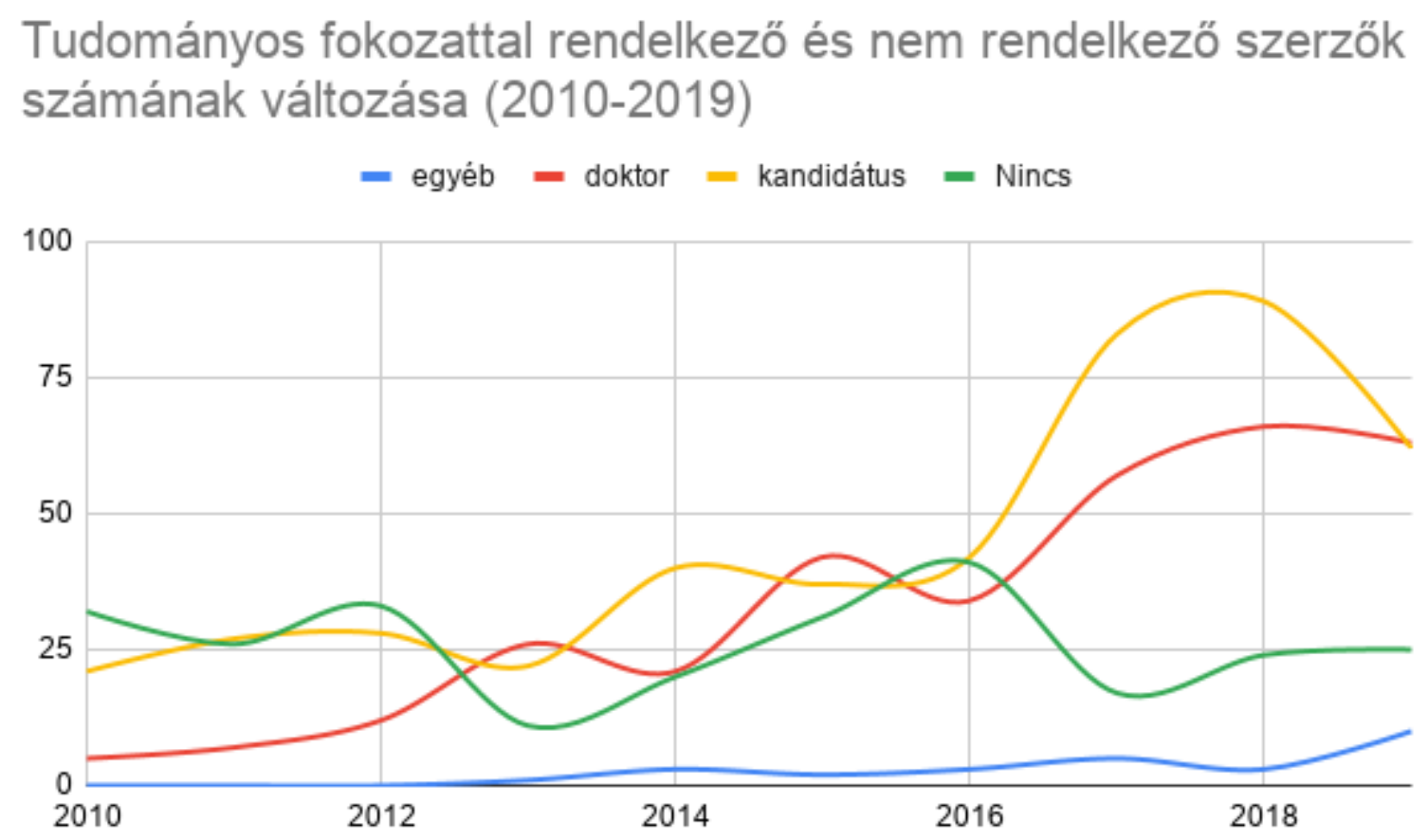

Azt vehetjük észre, hogy a tudományos fokozattal nem rendelkezők száma a vizsgált időszak elején még valamennyivel meghaladta azokét, akik rendelkeztek kandidátusi vagy doktori fokozattal. Ez két dologból tevődhet össze: egyrészt nem volt elegendő tudományosan kvalifikált idősebb szerző, másrészt jobban segíthették a fiatalabb aspiránsok fokozatszerzését, azaz az utánpótlás nevelését. Később viszont a fokozattal nem rendelkezők száma egyre inkább csökkenő tendenciát mutat. A 2015 végén megszerzett minősítés, miszerint a folyóirat a kandidátusi és doktori fokozatok megszerzéséhez szükséges publikációknak biztosít felületet láthatóan ideiglenes jó hatással volt a fokozattal nem rendelkezők arányára, azonban ez nem tartott sokáig. Viszont azok számára, akik a kandidátusi fokozattól a doktori fokozat felé igyekeznek, nagyobb felhajtóerőt biztosított. De ez a lendület az időszak végére kifulladni látszik, s egyre inkább a „doktorok” veszik át a vezető szerepet. Emellett rendkívül lassú, de növekvő tendenciát mutatnak a külföldön szerzett tudományos fokozatok.

Összességében tehát azt állapíthatjuk meg, hogy az idő előrehaladtával az akadémiai szisztémába való bekerülést egyre kevésbé segítik, de a rendszeren belüli mozgás valamivel 
könnyebb. Így viszont a folyóirat kezd egyrészt egyre elitistábbá válni, másrészt viszont egyre idézettebb lenni.

Végezetül érdemes megvizsgálni a szerzők affiliációját. Mivel az intézményi szinten való vizualizáció nem valósítható meg egyszerűen, ezért ennél az elemzésnél az egyes cikkek szerzőinek települései lettek figyelembe véve, eltekintve attól, hogy az adott településen hány tudományos intézmény található. Emellett a statikus térképen való ábrázolás nem tette lehetővé a diakrón megjelenítést, ezért az egész időszakra vonatkozó szinkrón összesítést közöljük, így eltekintünk a tudományos kapcsolatok dinamikájának vizsgálatától. A kapcsolatrendszert térképen ábrázolva az alábbiak rajzolódnak ki (alatta a 10 és afölötti előfordulás táblázatban):

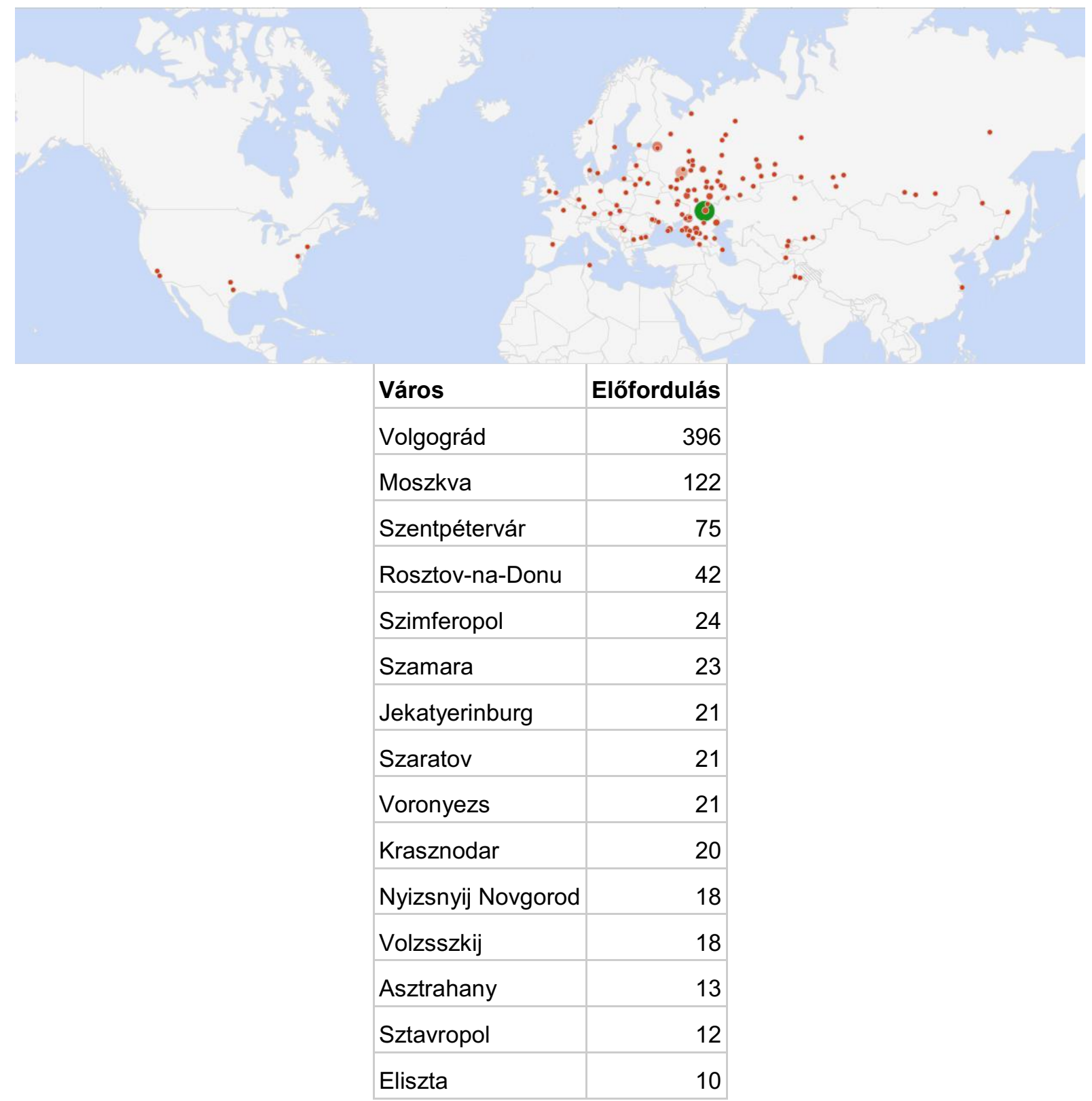


Összesen 127 különböző város kutatói publikáltak a lapban, de a cikkek szerzőinek bő 1/3-a, 396 Volgográdhoz kötődik. Ezen belül a folyóirat anyaintézményének számító Volgográdi Állami Egyetemhez 303, ami az összes szerzőségnek valamivel több, mint 1/4-e.

A következő két nagyobb gócpontot pedig a két föváros, Moszkva (11,35\% - 122) és Szentpétervár (ca. 7\% - 75) adja.

Ezt követik a regionális kapcsolatok. Ezek közül a legélénkebb a Rosztov-na-Donuval fenntartott, amely jelentős szövetségi egyetemmel és regionális akadémiai kutatóközponttal rendelkezik. Kiemelendő a többi szövetségi egyetem, amelyek közül sorrendben Szimferopollal, Jekatyerinburggal és Sztavropollal a legközelebbi a kapcsolat, továbbá a Volga-vidék nagyvárosai: Szamara, Szaratov, Nyizsnyij Novgorod, Volzsszkij (a Volgográdi Állami Egyetem filiáléja müködik itt), Asztrahany, valamint a szomszédos területek fôvárosai: Voronyezs (Voronyezsi terület) és Eliszta (Kalmükföld).

A folyóiratban ezen felül előfordulnak publikációk szinte az összes nagyobb oroszországi egyetemi központtól, de ezek, valamint külföldi kapcsolatok egyáltalán nem mondhatóak szisztematikusnak.

Mindenképpen szót érdemel Moszkva és Szentpétervár láthatóan kiemelt szerepe. Bár a folyóirat országosan biztosít publikálási lehetőséget, elsősorban regionális tudományszervezőként kíván fellépni. Ehhez képest mégis a két fővároshoz köthető a publikációk mintegy 20\%-a, ami közel megegyezik a 10 és afölötti publikációt szolgáltató összes többi város arányával ( 22,5\%). Ebben jól tükröződik az az objektív helyzet, hogy az intellektuális tőke eloszlása egyenetlen Oroszországban, s Moszkva és Szentpétervár jóval több rangos kutatóhellyel rendelkezik. Így országos gyüjtőkör esetén értelemszerűen jóval több publikáció is érkezik ezekről a helyekről. ${ }^{9}$ Meglátásunk szerint érdemes lenne tovább fejleszteni a regionális és nemzetközi kapcsolatokat, hogy ez a viszonylagos centralizáltság még jobban kiegyenlítődjön.

\footnotetext{
$9 \mathrm{Az}$ intellektuális tőke területi eloszlásáról 1. pl. А.С. МихАЙлов, «Территориальное распределение интеллектуального капитала в России», Высшее образование в России, Vol. 28. No. 6 (2019): 28 -39. https://vovr.elpub.ru/jour/article/view/1786/1323 (дата обращения: 24 сентября 2020 г.)
} 
Összegezve a szerzőkről szóló fejezetet, annak ellenére, hogy a szerzőgárda folyamatosan bővül, az orosz tudományos élet néhány komoly demográfiai, tudományszervezési, tudománymetriai jellegzetessége is kirajzolódik a folyóiraton keresztül, mint a patriarchaizálódás, az elitizálódás (vagy „belterjesedés”) és a viszonylagos centralizáltság.

\section{Rovatok}

A következőkben érdemes néhány pillantást vetni a rovatok megoszlására, amelyekből az egyes tudományterületek viszonyára következtethetünk, és bizonyos tudománypolitikai kérdések lecsapódását vizsgálhatjuk. Az alábbi két ábra közül az elsőn a rovatok százalékos megoszlását láthatjuk, a másodikon pedig ezek időbeli változását szemléltetjük:

\section{A cikkek megoszlása rovatonként}

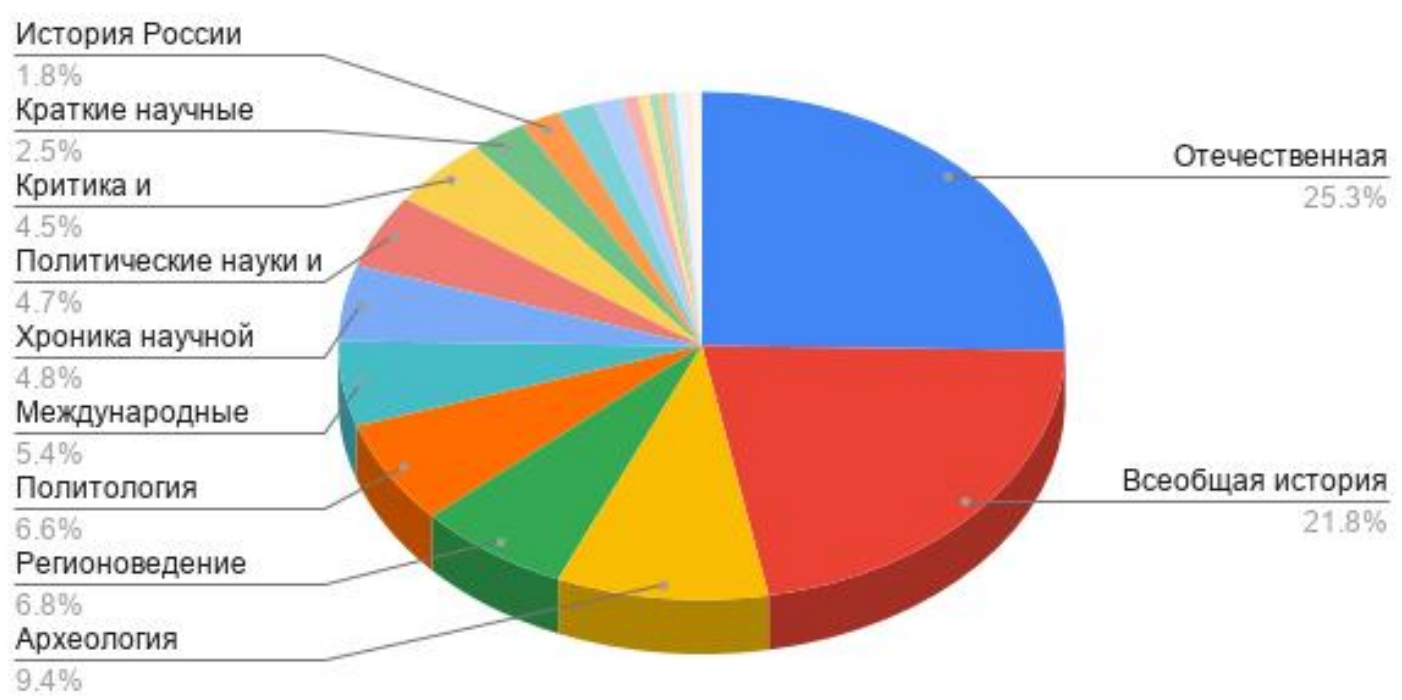




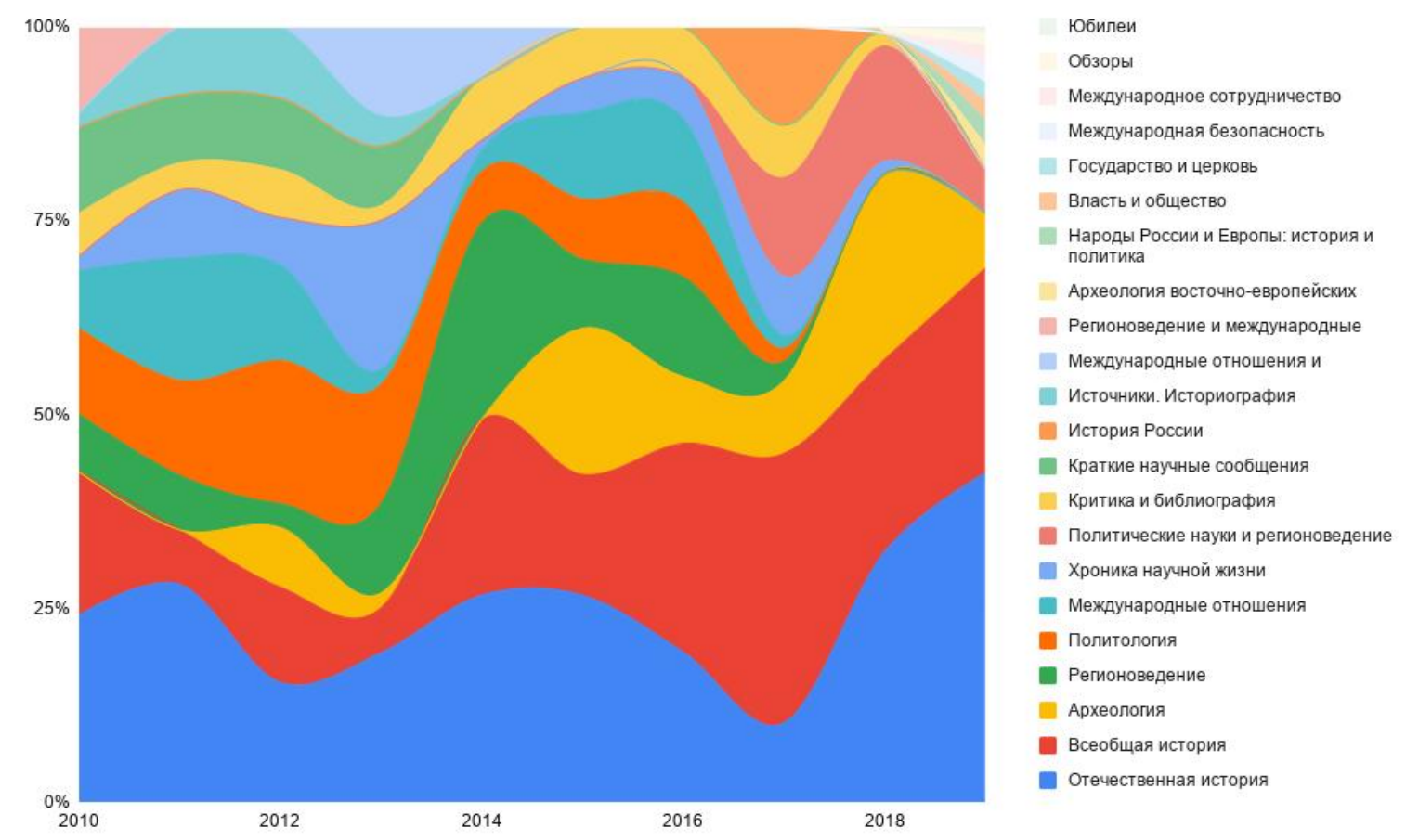

Az ábrákon jól látható, hogy a cikkek több mint felét a történettudományokhoz tartozó „hazai történelem" avagy orosz történelem, az egyetemes történelem és a régészet teszi ki. Az is jól látható, hogy míg 2014/2015 előtt igyekeztek fenntartani a különböző tudományterületek közötti egyensúlyt, az egyre inkább eme három tudományág felé tolódott. Ez magyarázható azzal, hogy a szerkesztőbizottságban ki és milyen területen rendelkezik a legnagyobb autoritással, szakmai kompetenciával és tudományos beágyazottsággal, és melyek az egyes diszciplínák legitimációs hagyományai az orosz tudományosságban. Az amerikanisztikával és nemzetközi kapcsolatokkal foglalkozó Kurilla után az orosz történelemmel foglalkozó Tyumencev inkább a saját területe felé vitte el a folyóirat profilját.

Emellett természetesen ehhez az arányhoz az is hozzájárult, hogy a vizsgált időszak alatt egyedül az „Orosz történelem” és az „Egyetemes történelem” számított állandó rovatnak, a folyóirat többi fö profilja, a nemzetközi kapcsolatok, a regionális földrajz és a politológia állandó változásban, különböző konstellációkban jelent meg. 2010 elején pl. még „Regionális földrajz és nemzetközi kapcsolatok” rovat létezett, de aztán hosszú időre külön váltak; 20132014-ben egy rövid ideig próbálkoztak a „Nemzetközi kapcsolatok és politológia” összevont rovattal, 2017-től pedig újabb összevonás következett „Politikatudományok és regionális földrajz” címmel, a „Nemzetközi kapcsolatok” pedig eltünt. 
Az utóbbi évek talán egyik legnagyobb „,nyertese” a régészet lett, amely az orosz történelemről 2012-ben leválva egyre nagyobb részesedést kapott, jelezve hogy a sztyeppei nem-orosz népek leletanyagának előkerülése és feldolgozása dinamikusan fejlődő terület. Ugyanakkor a forrásközlés és a historiográfia mint önálló rovat 2014-től teljesen eltünt a repertoárból, ami egyrészt arra enged következtetni, hogy a történettudomány területén az alapkutatások helyét inkább azok alkalmazása vette át, másrészt hogy a historiográfia betagozódott az orosz és egyetemes történelem rovataiba.

A vezető rovat az egész időszak alatt a „Hazai történelem” volt, ebben jelent meg a legtöbb cikk. Ez alól kivétel a 2012-es év, amikor a „Politológia” fölébe kerekedett, valamint 2016 és 2017, amikor az egyetemes történelem tárgykörébe tartozó terjedelmes bizantinológiai tematikus számok jelentek meg. A 2017-es visszaeséshez egy szemléletváltási kísérlet is hozzájárult, ugyanis a nemzeti jellegü „Hazai történelmet” (Отечественная история) felváltotta az objektívebben hangzó „Oroszország története” (История России). ${ }^{10}$ Azonban ez a szemléletváltás nem volt hosszú életű, s 2018-tól már újra a megszokott néven jelent meg a rovat.

Ennél jóval markánsabb szemléletváltást vetít elöre 2019 utolsó reguláris száma (Vol. 24. No. 5.), amelyben merőben új rovatcímek tünnek fel, úgymint: „A kelet-európai sztyeppe régészete”, „Oroszország és Európa népei: történelem és politika”, „Hatalom és társadalom”, „Állam és egyház”, „Nemzetközi biztonság” és „Nemzetközi együttmüködés”. Ez a gyors váltás egyébként vizuálisan is jól megfigyelhető a fejezethez tartozó második ábránk jobb felső sarkában. Jelen cikk megírásáig a 2020-as évfolyamból két tematikus és egy reguláris szám jelent meg. A reguláris szám (Vol. 25. No. 3.) rovatcím-választásai („SzSzSzK: a szovjet modernizáció problémái”, „A 20. század hadmüveletei”, „A 20. század katonai-politikai konfliktusai és megoldásai”, „Infokommunikációs folyamatok a közpolitikában”, „A historiográfia problémái”) arra engednek következtetni, hogy ez nem egyszeri kísérlet, hanem a folyóirat jövőjét meghatározó fordulat, s az olvasható ki belőle, hogy a több tudományágat egymás mellett, de egymástól elválasztva felvonultató, interdiszciplináris folyóirat ezzel a változtatással új szintre lépett. A tudományági felosztás helyett ugyanis az egyes témákat járja

\footnotetext{
${ }^{10}$ Ugyanezt a szemléletváltást figyelhettük meg Oroszország vezető történelmi folyóirata kapcsán, amely kb. 10 évvel korábban, 2008-ban váltott az Otyecsesztvennaja isztorija névröl Rosszijszkaja isztorijá-ra.
} 
körül különböző szempontokból, ami a valódi multidiszciplinaritás felé tett lépésként értelmezhető, ami a mai tudományos közegben rendkívül előremutató és üdvözlendő fejlődés.

\section{Kulcsszavak}

Munkahipotézisünk alapján a kulcsszavak gyakoriságának elemzése képet adhat arról, melyek a gyakran előforduló, ún. „forró témák”.

A vizsgált időszakban a szerzők összesen 5130 kulcsszót, kulcskifejezést helyeztek el cikkeik témájának azonosítására. Ez összességében 3590 különböző szót, kifejezést jelent, amelyeknek mintegy 83\%-a (2992) csupán egyszer fordul elő, vagyis a szerzők az esetek döntő többségében meglehetősen egyedi témamegjelöléseket alkalmaztak. ${ }^{11}$ A kulcsszavak előfordulása az említésszám függvényében exponenciálisan csökkenő tendenciát mutat. Az összes kulcsszó elemzésénél az ebből a trendből felfelé kiugró eseteket ismertetjük:

\begin{tabular}{|l|r|}
\hline Kulcsszavak (összes) & Említés \\
\hline Великая Отечественная война & 35 \\
\hline Византия & 35 \\
\hline Россия & 28 \\
\hline сарматы & 23 \\
\hline Нижнее Поволжье & 19 \\
\hline США & 19 \\
\hline историография & 17 \\
\hline История Византии & 17 \\
\hline Первая мировая война & 17 \\
\hline Сталинградская битва & 17 \\
\hline
\end{tabular}

Ahogyan a módszertani bevezetöben említettük, szükségesnek találtuk az elemzést elvégezni a tematikus számok kulcsszavai nélkül is, ugyanis a zárt tematika ösztönözhet a hozzájuk kapcsolódó kulcsfogalmak rutinszerü alkalmazásához, s ezáltal torzulhat az eredmény ezek javára. A nem tematikus cikkekben összesen 3534 kulcsszó jelent meg, amelyek közül 2590

11 Ehhez hozzá kell tenni, hogy a hasonló témakörbe tartozó, sokszor minimális mértékben eltérő szavak, kifejezések (pl. IV. Iván, Rettegett Iván, IV. [Rettegett] Iván) nem kerültek összevonásra. 
volt különböző, s ugyanúgy kb. 83\% (2168) volt egyszer használatos. A diverzitás tehát hasonlóan magas. Ennek a listának a vezérfogalmai a következők:

\begin{tabular}{|l|r|}
\hline Kulcsszavak (tematikus számok nélkül) & Említés \\
\hline Россия & 24 \\
\hline США & 19 \\
\hline Первая мировая война & 16 \\
\hline Нижнее Поволжье & 15 \\
\hline внешняя политика & 14 \\
\hline сарматы & 14 \\
\hline историография & 13 \\
\hline война & 12 \\
\hline Великая Отечественная война & 11 \\
\hline гражданское общество & 11 \\
\hline международные отношения & 11 \\
\hline модернизация & 11 \\
\hline молодежь & 10 \\
\hline СссР & 10 \\
\hline Сталинградская битва & 10 \\
\hline
\end{tabular}

A két lista összehasonlításából jól látható, hogy az egyes bizantinológiai, régészeti avagy II. világháborús különszámok erősen megváltoztatták a vezérfogalmak viszonyait. Ha ezeket leválasztjuk, jól kirajzolódnak azok a kérdéskörök, amelyek az egyes tudományágak képviselőit különösen érdeklik.

A történelem területén, noha - ahogyan korábban említettük - a historiográfia régóta nem képez külön rovatot, továbbra is szerves részét képezi a kutatási trendeknek, ami azt a korábbi következtetést igazolja, hogy az ilyen témájú cikkek betagozódtak az általános történelmi témájú cikkek közé. Emellett kiemelkedőek a 20. századi témák, mint az I. világháború, a II. világháború és általánosságban a Szovjetunió története. A regionális földrajz és helytörténet területén jól látható, hogy elsősorban az Alsó-Volga-vidék kutatása, valamint a sztálingrádi csata elemzése emelkedik ki. A régészet tudományágában a környező sztyeppe-vidéket a vaskorban és a népvándorláskorban benépesítő szarmaták kutatása élvez prioritást. A nemzetközi kapcsolatok területén pedig az rajzolódik ki, hogy elsősorban az Egyesült Államokkal való összehasonlítás és a háborúk kutatása uralkodik. A politológia területének 
legfontosabb kérdései pedig a polgári társadalom adaptációs lehetőségei, a modernizáció örök kérdése, valamint a Kelet-Európában tapasztalható demográfiai krízis szempontjából különösen fontos ifjúságpolitika.

Ha csak szükebb témánkat, a történeti ruszisztika tárgykörét vizsgáljuk, azaz a „Hazai történelem” ill. „Oroszország története” rovatcímmel ellátott cikkek kulcsszavait, akkor az alábbi megállapításokat tehetjük: ezekben a rovatokban összesen 1451 kulcsszó került alkalmazásra, s ez 1156 különböző egységet jelent. A szavak közül kb. 88,5\% (1023) csupán egyszer fordul elő, vagyis a kulcsszavak alapján a témák diverzitása valamivel nagyobb, mintha a teljes spektrumot vizsgálnánk. A kulcsszavak alapján három vezérfogalom körvonalazódik:

\begin{tabular}{|l|r|}
\hline Kulcsszó (orosz történelem) & Említés \\
\hline Великая Отечественная война & 29 \\
\hline Смутное время & 12 \\
\hline Сталинградская битва & 12 \\
\hline
\end{tabular}

Ezek közül a Nagy Honvédő Háború toronymagasan vezet, és holtversenyben második a „Zavaros Időszak”, valamint a sztálingrádi csata.

Azonban itt is figyelembe kell vennünk, hogy a II. világháborúról több tematikus kötet is megjelent, és a Rurik-dinasztia kihalása utáni időszaknak is szenteltek egy tanulmánykötetet. Ha ezeket a tematikus számokat levesszük, akkor 897 kulcsszó marad, amelyek közül 758 különböző van, és 89\%-uk (675) fordul elö egyszer. A két legtöbbször (összesen 7-7 alkalommal) említett vezérfogalom pedig a Nagy Honvédő Háború (Великая Отечественная война) és a rendkívül általános Oroszország (Россия).

Összességében tehát azt mondhatjuk, hogy a folyóirat hazai történelmi tematikájának gyújtópontjában a II. világháború (avagy Nagy Honvédő Háború) áll. Ez voltaképpen nem meglepő, hiszen a folyóirat székhelye egy olyan ikonikus helyen, a sztálingrádi csata helyszínén található, amely döntő jelentőségű ütközetnek számított a háború folyamán. A genius loci mellett azonban figyelembe kell venni azt is, hogy a mai orosz emlékezetpolitika milyen központi helyre emelte a Nagy Honvédő Háborút. A 7 cikk, amelyekben előfordul ez a kulcsszó, inkább arról árulkodik, hogy a háborúval és a sztálingrádi ütközettel kapcsolatos helytörténeti és regionális kutatásokon van a hangsúly. Ilyen például Oleszja Alekszandrovna 
Gomanyenko két cikke a volgai folyami flottilla tevékenységéről, ${ }^{12}$ Makszim Nyikolajevics Opalev írása a Vörös Hadsereg tüzérségi páncélvonatainak részvételéről a sztálingrádi csatában, ${ }^{13}$ valamint az elisztai Vlagyimir Badahajevics Ubusajev értekezése a kalmükföldi frontmunkások tevékenységéről az Asztrahany-Kizljar-vasútvonal építésekor. ${ }^{14}$ Emellett azonban előkerülnek országos jelentőségü témák is, mint pl. Anasztaszija Valerjevna Zotova és Szergej Nyikolajevics Poltorak szentpétervári kutatók cikke, amelyben az Állami Védelmi Tanács által kezelt hadizsákmányok historiográfiáját tekintik át, ${ }^{15}$ vagy a volgográdi Vlagyimir Vjacseszlavovics Sevcsenko munkája, amelyben a szolgálatból visszatért szovjet katonák GULAG-ba való zárásának kényes témáját feszegeti. ${ }^{16}$ Végül pedig egy nemzetközi kitekintésre is lehetőségünk van az Orosz Tudományos Akadémia Egyetemes Történeti Intézetének, valamint a Szamarai Állami Szociálpedagógiai Egyetem két munkatársának közremüködésével készült cikk segítségével, akik a leningrádi blokád egyesült államokbeli sajtóvisszhangját elemezték. ${ }^{17}$

12 О.А. ГомАНЕНКО, «Специфика работы Нижневолжского речного пароходства в 1944-1945 годах», Вестник Волгоградского государственного университета. Серия 4, История. Регионоведение. Международные отношения, Vol. 16. no. 1 (2011): 25-31. DOI: 10.15688/jvolsu4.2011.1.4, https://hfrir.jvolsu.com/index.php/ru/component/attachments/download/475 (Дата обращения: 8 сентября 2020 г.); О.А. ГОМАНЕНКО, «Навигация 1943 года: битва за Волгу продолжается», Вестник Волгоградского государственного университета. Серия 4, История. Регионоведение. Международные отношения, Vol. 24. no. 3 (2019): 115-125, https://hfrir.jvolsu.com/index.php/ru/component/attachments/download/1969 (Дата обращения: 8 сентября 2020 г.)

13 М.Н. ОПАЛЕВ, «Неизвестные страницы участия соединений артиллерийских бронепоездов Красной армии в Сталинградской битве годах», Вестник Волгоградского государственного университета. Серия 4, История. Регионоведение. Международные отношения, Vol. 16. nо. 2 (2011): 65-70. DOI: 10.15688/jvolsu4.2011.2.9, https://hfrir.jvolsu.com/index.php/ru/component/attachments/download/194 (Дата обращения: 8 сентября 2020 г.)

14 В.Б. УБУШАЕВ, «Вклад тружеников Калмыкии в строительство железной дороги Астрахань - Кизляр (октябрь 1941 - август 1942 г.)», Вестник Волгоградского государственного университета. Серия 4, История. Регионоведение. Международные отночения, Vol. 22. no. 3 (2017): 136-141. DOI: 10.15688/jvolsu4.2017.3.12, https://hfrir.jvolsu.com/index.php/ru/component/attachments/download/1421 (Дата обращения: 8 сентября 2020 г.)

15 А.В. ЗотОВА, С.Н. ПолторАК, «Деятельность Государственного Комитета Обороны по использованию трофеев в период Великой Отечественной войны», Вестник Волгоградского государственного университета. Серия 4, История. Регионоведение. Международные отночения, Vol. 22. no. 3 (2017) 126135. DOI: 10.15688/jvolsu4.2017.3.11,

https://hfrir.jvolsu.com/index.php/ru/component/attachments/download/1419 (Дата обращения: 8 сентября 2020 г.)

16 В.В. ШЕВЧЕНКО, «Режим содержания бывших военнослужащих в спецлагерях в 1942-1946 годах», Вестник Волгоградского государственного университета. Серия 4, История. Регионоведение. Международные отношения, Vol. 15. no. 2 (2010): 38-43. DOI: 10.15688/jvolsu4.2010.2.5, https://hfrir.jvolsu.com/index.php/ru/component/attachments/download/331 (Дата обращения: 8 сентября 2020 г.)

17 Д.В. СУРжик, С.О. БУРАНОк, Я.А. ЛЕВин, «Блокада Ленинграда в оценках прессы США», Вестник Волгоградского государственного университета. Серия 4, История. Регионоведение. Международные $\begin{array}{llllll}\text { отношения, } & \text { Vol. } & 24 . & \text { no. } & 1 & \text { (2019): }\end{array}$ https:/hfrir.jvolsu.com/index.php/ru/component/attachments/download/1880 (Дата обращения: 8 сентября 2020 г.) 


\section{A legnépszerübb cikkek}

A Vesztnyik 2014-től létező online archívuma 2020. január 21-ig több mint 700 ezer letöltést generált. ${ }^{18}$ Fontos megjegyezni, hogy a letöltések eme száma összesítve van megadva a honlap angol és orosz nyelvü változatára. Ezáltal arra is választ kaphatunk, hogy orosz, avagy oroszul kevésbé jól olvasó nemzetközi kutatók érdeklődtek-e jobban egyes témák után. Azt láthatjuk, hogy a legtöbb kattintást kapott írás Alekszandr Szergejevics Hodnyev, a Jaroszlavli K. D. Usinszkij Állami Pedagógiai Egyetem professzorának „Nemzetközi kapcsolatok és politológia” rovatban 2014-ben megjelent cikke. ${ }^{19}$ Ezt az angol nyelvü oldalról 8014-en, orosz oldalról 905en próbálták elérni. A mủ a Népszövetség létrejöttének kérdéseit közelíti meg újszerüen. Míg korábban a versailles-i békerendszerből próbálták levezetni kialakulását, Hodnyev rámutat, hogy már a századelőn voltak próbálkozások egy nemzetközi politikát szabályozó szervezet létrehozására, s 1916-1917-ben jelentős társadalmi vita zajlott létjogosultságáról az Egyesült Államokban és az Egyesült Királyságban, amelynek főszereplői a Fabiánus Társaság és Leonard Woolf voltak.

A második legnépszerübb cikk mintegy fele ilyen elérési számot generált, de ugyancsak angol oldalról próbálták elérni többen (4476 letöltés, míg orosz oldalról 281). Ez egy népszerü fiatal görög Amerika-kutató Konsztantinosz D. Karacasz 2016-os cikke az afroamerikai polgárjogi mozgalom három aspektusáról, a politikai, a jogi küzdelmekről, valamint a passzív ellenállás jelentőségéről. ${ }^{20}$

A harmadik legnépszerübb - és egyben az első orosz részről több kattintást generáló - cikk (orosz oldalról 4459, angol oldalról 224 letöltés) Dmitrij Vlagyimirovics Liszejcev, az Orosz Tudományos Akadémia Orosz Történeti Intézetének fiatalabb generációba tartozó tudományos

\footnotetext{
${ }^{18}$ Vitalij Alekszandrovics Gorelkin főszerkesztő-helyettes írásbeli közlése.

19 А.С. ХоДНЕВ, «Первая мировая война и дискуссии о создании универсальной международной организации», Вестник Волгоградского государственного университета. Серия 4, История. Регионоведение. Международнье отношения, Vol. 19. no. 5 (2014): 113-121. DOI: 10.15688/jvolsu4.2014.5.12, https://hfrir.jvolsu.com/index.php/ru/component/attachments/download/813 (дата обращения: 18 сентября 2020 г.)

${ }^{20}$ К.Д. КАРАТЗАС, «Использование пассивного сопротивления в ходе движения в защиту гражданских прав: анализ [На англ.]», Вестник Волгоградского государственного университета. Серия 4, История. Регионоведение. Международные отночения, Vol. 21. no. 1 (2016): 42-50. DOI: 10.15688/jvolsu4.2016.1.5, https:/hfrir.jvolsu.com/index.php/ru/component/attachments/download/1112 (дата обращения: 18 сентября 2020 г.). Fontos megjegyezni, hogy a letöltési adatbázis 2020. szeptember 11 -ei keltezésü, és mivel Karacasz egy másik hasonló témájú cikke a 4. legnépszerübb, elképzelhető, hogy az idén fellángoló Black Lives Mattermozgalom generálhatta ezt a magas kattintás-számot.
} 
főmunkatársának a „Zavaros Időszakról” szóló tematikus kötetben megjelent tanulmánya, amely önmagában is izgalmas címmel rendelkezik: „Az 1613-as Zemszkij Szobor: választási lehetőség nélküli választások vagy egy választási lehetőség választások nélkül?”. ${ }^{21}$ Ebben Mihail Romanov trónra kerülésének körülményeit elemzi új források bevonásával, $\mathrm{s}$ arra a következtetésre jut, hogy korántsem övezte széleskörü népakarat és egyetértés, sokkal inkább a kozákok fellépése segítette őt trónra Trubeckoj herceg és Pozsarszkij duumvirátusával szemben.

\section{Kitekintés - magyar vonatkozások}

Magyarországgal, magyar-orosz kapcsolatokkal foglalkozó cikk nem sürün jelent meg a folyóirat hasábjain. Eddig pusztán egyszer került a mai magyar politika a „Nemzetközi kapcsolatok" rovat érdeklődési körébe. Ilja Nyikolajevics Taraszov, a Balti Immanuel Kant Föderatív Egyetem politológia-professzora cikkezett 2015-ben a növekvő jobboldali radikalizmus és idegengyülölet társadalmi hátteréről közvélemény-kutatások és statisztikai adatok alapján. ${ }^{22}$

Emellett az epizódszerep mellett azonban fontos megemlíteni, hogy a szerkesztőbizottságban helyet foglal két magyar tag is: Ágoston Magdolna, a szombathelyi illetőségű Szláv Történeti és Filológiai Társaság korábbi elnöke, valamint Szvák Gyula, a történeti ruszisztika budapesti mühelyének alapítója.

Bár Volgográd kétségtelenül távol van tőlünk, és az egyetem sem tartozik a legnevesebbek közé, a tárgyalt folyóirat nemzetközi elismertséggel bír, és számos feldolgozásra érdemes anyagot szolgáltathat a magyar kutatók számára is. Gondolhatunk itt elsősorban a sztyeppei régészet eredményeire, az osztrák-magyar hadsereg magyar származású hadifoglyainak repatriálásának, valamint a II. világháború dokumentumainak feldolgozására, hiszen utóbbiak

\footnotetext{
${ }^{21}$ Д.В. ЛИСЕЙЦЕВ, «Земский собор 1613 г.: выборы без выбора или выбор без выборов?», Вестник Волгоградского государственного университета. Серия 4, История. Регионоведение. Международные $\begin{array}{lllllll}\text { отночения. } & \text { Vol. } & 24 . & \text { no. } & 2 & \text { (2019): } & 137-146 .\end{array}$ https:/hfrir.jvolsu.com/index.php/ru/component/attachments/download/1937 (дата обращения: 18 сентября 2020 г.)

${ }^{22}$ И.Н. ТАРАСОВ, «Правый радикализм и факторы ксенофобских социальных практик в Венгрии», Вестник Волгоградского государственного университета. Серия 4, История. Регионоведение. Международнье отношения, Vol. 20. no. 6 (2015): 55-62. DOI: 10.15688/jvolsu4.2015.6.6, https://hfrir.jvolsu.com/index.php/ru/component/attachments/download/1054 (Дата обращения: 8 сентября 2020 г.)
} 
között a megszálló magyar hadseregre vonatkozó információkat is találhatunk. A jövőben tehát több tudományterület képviselöinek is érdemes nyomon követni a Vesztnyik számait, és felvenni a kapcsolatot a helyi kutatókkal. 